\title{
Conservation of tree species through sustainable use: how can it be achieved in practice?
}

\author{
Adrian C. Newton
}

\begin{abstract}
Tree species have been the focus of increasing interest regarding the so-called conservation-through-use approach, which aims to achieve conservation by increasing the value of wild resources to local communities. Although tree species display many characteristics that increase their potential for sustainable use, the approach is rarely successful in practice. The reasons for this are examined with reference to case studies, considering five conditions needed for success: (1) sustainable harvesting, (2) no interaction between threats, (3) successful commercialization, (4) economic benefits received by producers, and (5) use of financial income to support conservation action. Case studies illustrate that even when the first four of these conditions are met, trade in forest products often provides insufficient financial returns to protect the forest against other threats. This highlights the importance of understanding the interactions between threats for conservation-through-use to be achieved, an issue illustrated by a conceptual model. Recommendations are presented indicating how the conservation of tree species through sustainable use may be achieved in practice. Critically, financial rewards of sustainable use need to be large enough to support practical conservation action, which is required to counter the many threats to which tree species are exposed.
\end{abstract}

Keywords Conservation-through-use, non-timber forest product, NTFP, sustainable use, timber, tree.

\section{Introduction}

$\mathrm{T}$ he role of harvesting in conservation of species has long been the subject of debate (Hutton \& LeaderWilliams, 2003). People have exploited wildlife throughout human history, causing extinction of numerous species in the process. Such exploitation continues to be one of the principal threats to species (Mace \& Reynolds, 2001). The scientific principles of sustainable resource management are relatively well established, particularly for economically valuable resources such as fisheries, but there has been a widespread failure to apply these principles to wild populations (Milner-Gulland \& Mace, 1998; Ludwig, 2001). For these reasons, the active promotion of sustainable use as

Adrian C. Newton School of Conservation Sciences, Bournemouth University, Talbot Campus, Poole, Dorset, BH12 5BB, UK. E-mail anewton@ bournemouth.ac.uk

Received 29 March 2007. Revision requested 2 July 2007.

Accepted 25 October 2007. a conservation strategy has been highly controversial (Hutton \& Leader-Williams, 2003).

Most research on the exploitation of species has focused on vertebrate animals, particularly mammals and fish, and relatively little on trees. This is despite their high socioeconomic importance: the global trade in forest products is now worth $c$. USD 159 billion annually (FAO, 2005). However, in recent years the conservation-through-use (or use it or lose it) approach (Plotkin \& Famolare, 1992; Johnson \& Cabarle, 1993; Richards, 1993; Dickinson et al., 1996; Neumann \& Hirsch, 2000) has attracted interest in the context of tropical forest conservation. This approach is based on the contention that forests can be conserved if rural communities gain some direct economic benefit from harvesting forest products (Dickinson et al., 1996; Freese, 1997). Based on this idea, the commercial development of tropical forest resources has been widely promoted by conservation and development organizations (Neumann \& Hirsch, 2000; Sheil \& Wunder, 2002). Only recently, however, has the effectiveness of this approach been critically examined (Marshall et al., 2003, 2006; Kusters et al., 2006).

Millions of people depend on exploitation of wildlife to support their livelihoods and this dependence is likely to continue. The integration of conservation and use is therefore not an option but an imperative. Consequently, research is needed to define how conservation and use of species can be successfully combined (Milner-Gulland \& Mace, 1998; Hutton \& Leader-Williams, 2003). Research on animal species has indicated that the sustainability of use, whether for subsistence or commercial purposes, depends on human institutions as much as the biological characteristics of the species concerned (Hutton \& Dickson, 2001). Furthermore, the concept of sustainable use has itself been variously interpreted, depending on what is being sustained: wild populations of species, ecosystem structure or function, or human livelihoods (Robinson, 2001). Here, the term sustainable use refers to the maintenance of viable populations of species that are harvested by humans.

Trees differ from animals in a number of characteristics that influence their potential for sustainable use: as trees are stationary and generally less cryptic than animals, exploitation may be relatively easy to observe (Peters, 2001); many species are hermaphroditic, reducing dependence on the presence of a mate for reproduction (although many are dependent on outcrossing); typically, trees have high reproductive output and some are able to reproduce vegetatively (Peters, 2001); many products (such as leaves, fruits, nuts and latex) can be harvested without killing individuals. 
Together with extreme longevity of individuals, these characteristics confer relatively high potential for sustainable use.

As with many animal groups, over-exploitation is a major threat to tree species. In a global assessment of the threats affecting 4,585 tree taxa that are considered threatened with extinction (Oldfield et al., 1998), 1,683 $(36.7 \%)$ were found to be threatened by some form of use, a similar proportion to that recorded for birds and mammals (Mace \& Reynolds, 2001). Some $25 \%$ of threatened tree species have at least one recorded use, the most common of which is harvesting for timber (Oldfield et al., 1998). However, tree species are subjected to a variety of threats that often act in combination. Widespread threats include conversion of forest to agricultural land, urban expansion, habitat fragmentation, browsing by livestock, invasive species and the use of fire (Oldfield et al., 1998; Newton, 2007). For conservation action to be effective, all threats must be addressed.

A number of authors have considered the factors that influence the conservation of exploited populations, e.g. the importance of specific management goals (Robinson, 2001), the provision of financial incentives (Hutton \& LeaderWilliams, 2003), political will and governance, and the overriding importance of market forces (Milner-Gulland \& Mace, 1998). Here I critically examine whether the conservation-through-use approach, which has been widely promoted as a means of conserving tropical forests, can contribute to the conservation of tree species. I propose that for this to occur, the following five conditions need to be met: (1) harvesting of forest products must be sustainable, in terms of maintaining viable populations of the tree species being harvested; (2) harvesting of forest products must not interact positively with other threats; (3) commercialization of the forest product must be economically viable; (4) the economic benefits from commercialization must be received by those harvesting the wild resource; (5) the income received from commercialization must act as an incentive to conserve the tree species being harvested.

Each of these five conditions is considered with reference to case studies. The focus here is on conservation of tree species, and not on forests. These two objectives do not necessarily coincide. Also, the focus here is on the role of commercial exploitation rather than on subsistence use, because it is only trade in a forest product that can increase the income received by harvesters. The conservationthrough-use approach considered here is equivalent to the conservation through sustainable use concept as defined in relation to animal species (Webb, 2002).

\section{(1) Sustainable harvesting}

The concept of sustainable management has broadened beyond sustained yield concepts to encompass the wider environmental and socio-economic impacts of harvesting
(Weddell, 2002). In forestry this broader concept is referred to as sustainable forest management, which has been the central focus of international forest policy initiatives since 1992 (Wiersum, 1995; Nussbaum \& Simula, 2005).

It should not be assumed that all species sourced from a forest considered to be sustainably managed will necessarily themselves be sustainably harvested, in terms of maintaining viable populations. For example, management of peat swamp forests in Sarawak achieved a sustainable yield in terms of total timber volume but the most valuable timber species in this forest type (ramin Gonystylus bancana) was severely overcut (ITTO, 1990). Similarly, in the forests of Quintana Roo, Mexico, regeneration of mahogany Swietenia macrophylla is inadequate to maintain current population size, despite having been certified as sustainable (Snook, 1996, 2003).

Mahogany provides an instructive example of how the use of an individual species can conflict with the broader aim of sustainable forest management. The species is generally considered to require large-scale disturbance to regenerate successfully because it is light-demanding as a young tree (Gullison et al., 1996; Gullison, 1998; Snook, 2003; but see Brown et al., 2003). Selective logging typically does not create sufficient disturbance to provide opportunities for seedling establishment (Gullison et al., 1996; Snook, 2003). The disturbance required to secure substantial regeneration would have major negative impacts on other species in the community. Other threatened tree species such as Fitzroya cupressoides, Pilgerodendron uviferum and Pinus chiapensis (Table 1) similarly depend on major disturbance for regeneration, limiting scope for their sustainable management.

Of the 10 species considered here (Table 1), for only four is use sustainable in at least some situations. Significantly, in each of these cases the product being harvested is a nontimber forest product (NTFP). This supports the general view that the potential for sustainable use is higher for many NTFPs than for timber, as the individual plants are often able to survive the harvesting process (Peters, 2001). However, in practice many NTFPs are also harvested destructively, leading to declines in abundance of many economically valuable species (Peters, 1996).

How then can sustainable use of a tree species be achieved in practice? I propose that this occurs by three principal means: (a) Serendipity (for example, if the amount harvested is low relative to the size of the resource, or if harvesting has little impact on the individual plant). (b) Static harvest controls (involving control of harvest without any reference to monitoring information; examples include community norms, culture or tradition, and protective legislation such as harvest quotas and licences). (c) Dynamic harvest controls (involving the regulation of the amount harvested in response to appropriate monitoring of the status of the resource; this is a key component of adaptive management). 
TABLE 1 Ten examples of tree species of conservation concern that are subjected to human use, with area of origin, any CITES Appendix listing (CITES, 2008) and IUCN Red List status (IUCN, 2007), principal uses, sustainability and threats. These species were selected here as case studies as each has been the focus of recent research in which the author has been personally involved. Further information on the conservation ecology of a number of these species is presented in Newton (2007).

\begin{tabular}{|c|c|c|c|c|c|c|c|c|}
\hline Scientific name & Common name & Area of origin & $\begin{array}{l}\text { CITES } \\
\text { Appendix }\end{array}$ & $\begin{array}{l}\text { Red } \\
\text { List } \\
\text { status }^{1}\end{array}$ & Principal uses & $\begin{array}{l}\text { Sustainability of } \\
\text { current use }\end{array}$ & Other principal threats & References \\
\hline Aquilaria malaccensis & $\begin{array}{l}\text { Gaharu, } \\
\text { eaglewood }\end{array}$ & South-East Asia & II & VU & $\begin{array}{l}\text { Resin obtained } \\
\text { from infected } \\
\text { wood }\end{array}$ & $\begin{array}{l}\text { Traditional harvesting } \\
\text { apparently sustainable; } \\
\text { currently unsustainable } \\
\text { exploitation is widespread }\end{array}$ & $\begin{array}{l}\text { Deforestation caused by } \\
\text { conversion to agriculture; } \\
\text { widespread fire }\end{array}$ & $\begin{array}{l}\text { Soehartono \& Newton } \\
(2000,2001,2002), \\
\text { Newton \& Soehartono } \\
(2001), \text { Paoli } \text { et al. }(2001)\end{array}$ \\
\hline Araucaria araucana & $\begin{array}{l}\text { Monkey puzzle, } \\
\text { pehuén }\end{array}$ & Chile, Argentina & I & VU & Nuts, timber & $\begin{array}{l}\text { Nut harvesting is } \\
\text { sustainable; no sustainable } \\
\text { timber harvesting }\end{array}$ & $\begin{array}{l}\text { Illegal logging; fire; } \\
\text { browsing by livestock }\end{array}$ & $\begin{array}{l}\text { Aagesen }(1998), \text { Bekessy } \\
\text { et al. }(2002,2004), \\
\text { Herrmann }(2005,2006)\end{array}$ \\
\hline Bertholletia excelsa & $\begin{array}{l}\text { Brazil nut, } \\
\text { castanha }\end{array}$ & South America & & VU & Nuts, timber & $\begin{array}{l}\text { Demographic analysis } \\
\text { suggests unsustainable } \\
\text { harvesting of seed is } \\
\text { widespread }\end{array}$ & $\begin{array}{l}\text { Deforestation \& forest } \\
\text { degradation; fire }\end{array}$ & $\begin{array}{l}\text { Myers et al. (2000), } \\
\text { Peres et al. }(2003)\end{array}$ \\
\hline $\begin{array}{l}\text { Fagus grandifolia } \\
\text { var. mexicana }\end{array}$ & Mexican beech & Mexico & & $\mathrm{VU}^{2}$ & $\begin{array}{l}\text { Timber, } \\
\text { fuelwood }\end{array}$ & $\begin{array}{l}\text { No sustainable } \\
\text { exploitation }\end{array}$ & $\begin{array}{l}\text { Deforestation caused by } \\
\text { conversion to agriculture; } \\
\text { browsing by livestock; fire; } \\
\text { climate change }\end{array}$ & $\begin{array}{l}\text { Williams-Linera et al. } \\
\text { (2003), Rowden et al. } \\
\text { (2004), Téllez-Valdés } \\
\text { et al. (2006) }\end{array}$ \\
\hline Fitzroya cupressoides & Alerce & Chile, Argentina & I & EN & Timber & $\begin{array}{l}\text { No sustainable } \\
\text { exploitation }\end{array}$ & $\begin{array}{l}\text { Illegal logging; fire; } \\
\text { browsing by livestock }\end{array}$ & $\begin{array}{l}\text { Allnutt et al. (1999), } \\
\text { Silla et al. (2002), } \\
\text { Premoli et al. (2003) }\end{array}$ \\
\hline Magnolia sharpii & Sharp's magnolia & Mexico & & $\mathrm{EN}^{3}$ & Leaves, timber & $\begin{array}{l}\text { Traditional use likely to be } \\
\text { sustainable }\end{array}$ & $\begin{array}{l}\text { Deforestation caused by } \\
\text { conversion to agriculture }\end{array}$ & $\begin{array}{l}\text { Galindo-James et al. } \\
\text { (2002), González-Espinosa } \\
\text { et al. (2006), Newton } \\
\text { et al. (2008) }\end{array}$ \\
\hline $\begin{array}{l}\text { Pilgerodendron } \\
\text { uviferum }\end{array}$ & $\begin{array}{l}\text { Ciprés de las } \\
\text { Guaitecas }\end{array}$ & Chile, Argentina & I & VU & Timber & $\begin{array}{l}\text { No sustainable } \\
\text { exploitation }\end{array}$ & $\begin{array}{l}\text { Illegal logging; fire; } \\
\text { browsing by livestock }\end{array}$ & $\begin{array}{l}\text { Premoli et al. (2001, } \\
\text { 2002), Allnutt et al. (2003) }\end{array}$ \\
\hline Pinus chiapensis & $\begin{array}{l}\text { Cuctoj, ocote, } \\
\text { palo-pique, pino } \\
\text { blanco, tonatzin }\end{array}$ & $\begin{array}{l}\text { Mexico, } \\
\text { Guatemala }\end{array}$ & & VU & Timber & $\begin{array}{l}\text { Little or no sustainable } \\
\text { exploitation }\end{array}$ & $\begin{array}{l}\text { Illegal logging; } \\
\text { deforestation caused by } \\
\text { conversion to agriculture; } \\
\text { lack of forest disturbance }\end{array}$ & $\begin{array}{l}\text { del Castillo \& Acosta } \\
(2002), \text { Newton } \\
\text { et al. (2002), del Castillo, } \\
\text { et al. (2004) }\end{array}$ \\
\hline Swietenia macrophylla & Mahogany, caoba & $\begin{array}{l}\text { Central \& South } \\
\text { America }\end{array}$ & II & VU & Timber & $\begin{array}{l}\text { Unsustainable exploitation } \\
\text { is widespread; a small } \\
\text { number of forests certified } \\
\text { as sustainable }\end{array}$ & $\begin{array}{l}\text { Deforestation caused by } \\
\text { conversion to agriculture; } \\
\text { illegal logging }\end{array}$ & $\begin{array}{l}\text { Gullison et al. (1996), } \\
\text { Snook (1996, 2003, 2005), } \\
\text { Gullison (1998), } \\
\text { Gillies et al. (1999) }\end{array}$ \\
\hline Ternstroemia lineata & Tila & Mexico & & $\mathrm{EN}^{4}$ & $\begin{array}{l}\text { Flowers, } \\
\text { timber }\end{array}$ & $\begin{array}{l}\text { Flower harvesting } \\
\text { apparently sustainable, } \\
\text { timber harvesting is not }\end{array}$ & $\begin{array}{l}\text { Deforestation caused by } \\
\text { conversion to agriculture; } \\
\text { timber logging }\end{array}$ & $\begin{array}{l}\text { Marshall \& Newton } \\
(2003)\end{array}$ \\
\hline
\end{tabular}

${ }^{1} \mathrm{VU}$, Vulnerable; EN, Endangered

${ }^{2}$ Not yet listed on IUCN (2007) but considered VU by Williams-Linera et al. (2003).

${ }^{3}$ Not yet listed on IUCN (2007) but considered EN by Cicuzza et al. (2007).

${ }^{4}$ Red List assessment currently in progress; preliminary assessment indicates EN. 
Case studies (Table 1) provide examples of these different approaches. For example, harvesting of Magnolia sharpii leaves for wrapping food, or Ternstroemia lineata fruit for making beverages (Marshall \& Newton, 2003), are examples of the first approach. In both cases, impacts of harvesting are relatively slight, and are unlikely to threaten tree populations significantly. Araucaria araucana provides an example of the second category, as some care is taken to limit the amount of seed harvested, although no formal monitoring of the resource is carried out (Herrmann, 2006). The amounts of seed harvested for trade have little impact on population viability (Bekessy et al., 2004). A. araucana is listed on CITES Appendix I and is also protected by national regulations designed to prevent exploitation for timber.

Aquilaria malaccensis is listed on CITES Appendix II and, as a consequence, trade is regulated by imposition of quotas and licences. However, harvest quotas are not based on accurate inventories of remaining stocks (Newton \& Soehartono, 2001). The case of A. malaccensis is informative in another way. Traditional approaches to harvesting gaharu from this species involved carefully selecting the target trees and felling only a proportion of them, a process guided by consultation with ancestral spirits. In recent years this method of harvesting has declined, associated with an increase in harvesting by incomers. As a result, over-exploitation is now widespread (Soehartono \& Newton, 2002; see also Jensen \& Meilby (2008), for the related A. crassna).

Ideally, for sustainable harvesting of a tree species to be achieved, the third of these approaches should be adopted, involving some form of adaptive management (Webb, 2002). Peters (1994) describes the main features of such an approach, highlighting the importance of monitoring the impact of harvesting on tree populations and adjusting the amount harvested in the light of the monitoring results. Such an approach is rarely, if ever, implemented (Peters, 1996). Arguably, without an adaptive management approach harvesting can never be genuinely sustainable. Hellier et al. (1999) provide an example of how traditional patterns of use, without any formal monitoring, can lead to local extinction of valuable timber species such as mahogany.

\section{(2) Interactions between threats}

Effective conservation depends on identifying and countering threats that increase the risk of extinction. Considered in these terms, the conservation-through-use approach can be seen as a trade-off between two threats: an increase in one threat (i.e. use) should reduce risk of another (i.e. conversion of forest to some other land use). In reality, tree species are typically subjected to multiple threats simultaneously (Table 1), and it is the dynamics and interactions of these threats that will determine their survival.

Homma (1996) provides a conceptual model describing the economic dynamics of forest products, which describes the typical boom and bust cycle of commercial exploitation (Fig. 1a). This model also provides a framework for considering the dynamics of different threats that can occur as a forest product is commercially exploited, an issue not considered previously (Fig. lb). This illustrates the possibility that extinction risk could continue to rise throughout the exploitation process if a positive interaction occurs between exploitation and another threat. The most likely such interaction is between harvesting and conversion of forest to agriculture. Timber harvesting can increase access to forest areas, and provide an opportunity for further colonization and agricultural expansion (Fearnside, 1997; Fredericksen \& Putz, 2003). Harvesting and agricultural conversion can potentially interact throughout the exploitation cycle, resulting in a higher risk of extinction than would be caused by harvesting alone. For the conservation-through-use approach to be successful, there must be no such positive interaction: increased production should decrease the risk of agricultural conversion by increasing the value of the forest resource.

Other threats may also interact positively with exploitation. For example, development of a road or track network in a forested area may improve access by livestock as well as people, resulting in browsing impacts, and may also lead to increases in other threats such as fire (Holdsworth \& Uhl, 1997). Research in Mexico and Chile has highlighted a complex series of interactions between infrastructural development, harvesting, forest fragmentation, browsing by livestock and fire, producing positive feedback loops of forest degradation caused by human activity (Newton, 2007).

\section{(3) Success of commercialization}

Commercial use refers to sale of a product in exchange for cash (Marshall et al., 2006). Although commercialization of NTFPs has been widely promoted as a means of developing tropical forest resources, the approach has often failed (Neumann \& Hirsch, 2000; Sheil \& Wunder, 2002; Ros-Tonen \& Wiersum, 2005; see also Gubbi \& MacMillan, 2008). This failure can take many forms. Here I focus on the commercial viability of the trade in forest products.

The viability of any commercial enterprise depends on there being a demand for a particular product and on being able to supply the product to consumers at a price they are prepared to pay. Profitability depends on achieving sufficient income at the point of sale to more than cover the costs of production, processing, transport and marketing. The marketing networks for forest products can be highly dynamic and complex (Neumann \& Hirsch, 2000), and how marketing networks function has a critical bearing on the commercial viability of the enterprise, as well as on the distribution of benefits between the people involved.

An examination of 19 case studies in Mexico and Bolivia showed that a wide range of factors influenced the success 
(a)

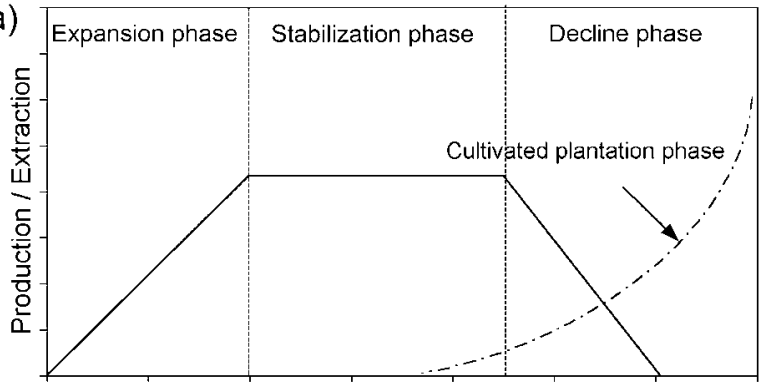

(b)

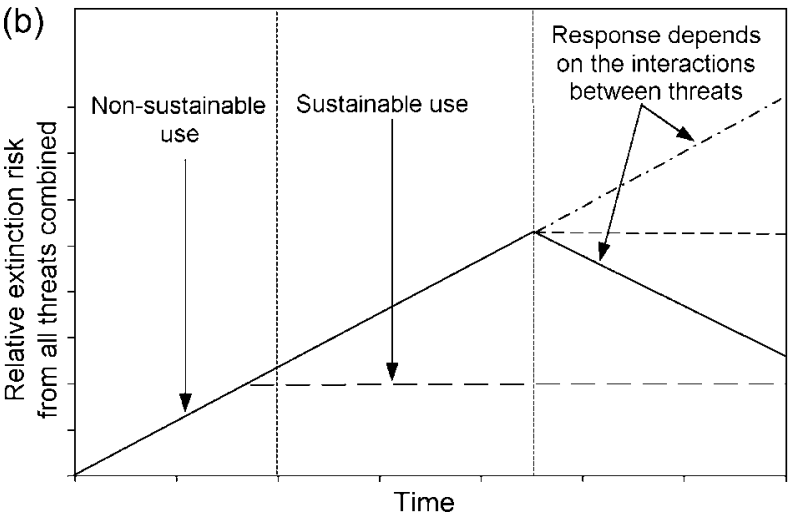

FIG. 1 (a) The historical cycle of forest production developed by Homma (1996), based on observations in Amazonia. In the model, four phases are differentiated. The expansion phase is characterized by growth in extraction, which is encouraged by the existence of a substantial resource and the demand for a product. This is followed by the stabilization phase, when supply and demand reach an equilibrium and production is constant. The decline phase is characterized by declining production, caused by a reduction in quality and quantity of the resource base as a result of over-exploitation, and increased cost of harvest. Homma (1996) lists a number of Amazonian forest products that are currently at different stages of this cycle, including timber species such as mahogany in the expansion phase, Brazil nut Bertholletia excelsa in the stabilization phase, and cocoa in the decline phase. For some species, decline in the wild resource may be accompanied by development of an alternative, cultivated resource (the cultivation phase) if the species is amenable to domestication. Cocoa provides an example of a species currently harvested from both wild and domesticated resources. (b) A conceptual model of the dynamics of extinction risk during the exploitation cycle. During the expansion phase, as the volumes of harvested product increase, this is likely to increase progressively the extinction risk of populations of the species being harvested. Extinction risk is likely to continue to rise during the stabilization phase as a result of over-exploitation, as it is supply and demand that are in equilibrium during this phase, not the amount harvested and productive capacity. Over-exploitation is therefore likely, leading to the decline phase. At this point, extinction risk may display different subsequent trajectories. For example, as production collapses, harvesting may decline and the resource may recover, if it still retains the capacity to do so. This would result in a decline in extinction risk. If exploitation has occurred to such an extent that recovery is impossible, extinction risk would remain stable. There is also a third possibility: that extinction risk will continue to rise because of a positive interaction between exploitation and another threat. of NTFP commercialization (Marshall et al., 2006; Newton et al., 2006), the most important of which related to product marketing (Table 2). These results support Homma's (1996) suggestion that producers often have little market information about products, prices or consumer preferences. Another important finding was that most NTFP value chains are demand driven; attempts to develop a new enterprise solely on the basis of existing supply are unlikely to succeed (Marshall et al., 2006). Many forest products are of relatively low value and can readily be substituted by other products. Steps towards domestication of the traded species were reported in $45 \%$ of the case studies (Marshall et al., 2006), something that is known to be a likely response to over-exploitation of a wild resource (Homma, 1996). Successful domestication can make a positive contribution to the commercial viability of forest products but because of biological or technological constraints many tree species are difficult to domesticate (Leakey \& Newton, 1994). Whether the domestication of a tree species affects its conservation status in the wild has not been researched. Proponents of tree domestication frequently suggest that successful cultivation may reduce pressure on natural resources but the evidence is scant (Newton, 1996). The problems of achieving conservation-through-use by domestication are illustrated by cultivation of Abies guatemalensis (Strandby Andersen et al., 2008); even when the technical and socio-economic challenges of domesticating a forest tree can be overcome, there may still be a need for awarenessraising among consumers and prevention of illegal harvesting. Conversion to plantation forestry can also be a major factor causing loss of natural forests, as in Chile (Newton, 2007). Whatever the relationship between domestication and conservation status, there is no doubt that domestication could undermine the conservation-through-use approach by providing a competing source of the product, or by promoting forest clearance.

\section{(4) Economic benefits to producers}

The commercial trade in forest products often provides limited economic returns to harvesters (Neumann \& Hirsch, 2000; see also Gubbi \& MacMillan, 2008). The reasons for this lie in the structure and function of market networks (or chains) and in the relationships between different bodies involved in the network, which may involve exploitation, cooperation, collusion or resistance (Neumann \& Hirsch, 2000). Exploitation of producers by intermediaries appears to be widespread. For Aquilaria, for example, collectors typically borrow money from intermediaries to finance collecting trips. The amounts can be substantial (USD 1,000-2,000) and many (73\%) collectors struggle to repay their loans (Soehartono \& Newton, 2002). This is a form of debt peonage, which is widespread in forest product market chains (Neumann \& Hirsch, 2000). 
TABLE 2 Factors limiting successful NTFP commercialization in more than 60\% of NTFP case studies examined in Mexico and Bolivia (from Marshall et al., 2006). The case studies included a range of products derived from different fungal and plant species that are currently being exploited commercially. Products derived from tree species included cocoa beans and paste derived from Theobroma cacao, natural rubber derived from Hevea brasiliensis, incense (copal) derived from Clusia and Protium spp., and leaves/fibre from Brahea dulcis.

Factor

$\%$ of case studies for which the factor limits

Structure \& function of the value chain

commercialization

Inequitable exertion of market power along the value chain

79

Price of the product does not vary in response to changing costs of production

Low development of the brand identity

Lack of an organization that links producers or processors to buyers

NTFP value chain does not use the value chain of other products

Lack of provision of financial capital to commercialization (e.g. credit \& loans) by entrepreneurs

No traditional link between producers \& consumers

Producers do not have good access to market information (price, quantity, quality)

Consumer preference for product quality is not reflected in the price paid to producers

Lack of entrepreneurs facilitating NTFP commercialization (e.g. through market information \& contacts)

Community social \& economic context

Lack of a communication network

No external financial support available in the form of credit or loans

Low level of integration of producers into the cash economy

Natural resource issues

NTFP quality is adversely affected by poor harvesting methods

Limited amount of resource available

Competing land uses for NTFP production areas

74

74

74

68

68

68

68

63

63

68

68

63

74

68

63
Inequitable exertion of market power along the value chain was cited by producers as the most widespread problem in the 19 case studies examined in Mexico and Bolivia (Marshall et al., 2006; Table 2).

The solution to this issue lies partly in improved organization, which can decrease economic vulnerability, help share costs, and improve a community's chances of attracting traders. Producer organizations can strengthen negotiations with traders, reducing the risk of exploitation (Marshall et al., 2006). The importance of such organizations is widely recognized. For example, in the case of T. lineata (Table 1), 93\% of women supported the formation of a cooperative gathering and selling organization (Marshall \& Newton, 2003).

\section{(5) Income from trade as an incentive for conservation}

It is difficult to evaluate whether or not the income derived from sale of forest products acts as an incentive for the conservation of tree species, or of forest, as required by the conservation-through-use approach. This requires an understanding of the decision-making process by rural communities regarding their livelihood options, an issue that has been little researched. However, given that the financial returns from the sale of forest products are often low, their contribution to conservation is likely to be limited. In Mexico and Bolivia resource decline was identified in $75 \%$ of cases (Marshall et al., 2006). In at least $15 \%$, income from NTFP sale was insufficient to prevent forest clearance.

Patterns of land tenure and forest ownership can have a major influence on decisions to harvest, and to invest in future harvests. Aquilaria is typical of many forest products in being treated as an open access resource, and therefore there is little incentive or opportunity for producers to allocate a proportion of income to conservation activities. Where forests are privately or communally owned, the potential for such an allocation is much higher (Table 3), although there is limited evidence for this occurring in practice. Some tree species are afforded a degree of protection because of their socio-economic or cultural value, such as communally owned groves of $A$. araucana maintained for seed collection (Aagesen, 1998; Herrmann, 2005, 2006).

Forest products generally have much lower economic value than agricultural products. It is therefore difficult for forest to compete economically with agricultural land use. Estimates suggesting that the economic value of forest products can exceed that of alternative agricultural land uses have proved to be misleading (Sheil \& Wunder, 2002). The potential for conservation-through-use is therefore likely to be highest where the demand for agricultural land is low, as in the case of natural rubber in Bolivia (Marshall et al., 2006). 
TABLE 3 Simplified assessment of the scope for conservation-through-use, with reference to selected tree species (Table 1), based on consideration of the five conditions required for the approach to be successful (see text for details).

\begin{tabular}{|c|c|c|c|c|c|c|}
\hline Scientific name & $\begin{array}{l}\text { (1) Potential for } \\
\text { sustainable harvesting }\end{array}$ & $\begin{array}{l}\text { (2) No interactions } \\
\text { between threats }\end{array}$ & $\begin{array}{l}\text { (3) Successful } \\
\text { commercialization }^{3}\end{array}$ & $\begin{array}{l}\text { (4) Economic benefits } \\
\text { received by producers }\end{array}$ & $\begin{array}{l}\text { (5) Income acts as an } \\
\text { incentive for conservation }\end{array}$ & $\begin{array}{l}\text { Overall potential for } \\
\text { conservation-through-use }\end{array}$ \\
\hline A. malaccensis & Low & Low & High & Low & Low & Low \\
\hline A. araucana seed & High & High & High & High & High & Very high \\
\hline A. araucana timber & Low & Low & High & High & High & Moderately high \\
\hline B. excelsa & High & High & High & High & High & Very high \\
\hline F. grandifolia var. mexicana & Low & Low & Low & High & High & Moderately low \\
\hline F. cupressoides & Low & Low & High & High & High & Moderately high \\
\hline M. sharpii & High & High & Low & High & High & High \\
\hline P. uviferum & Low & Low & High & High & High & Moderately high \\
\hline P. chiapensis & Low & Low & High & High & High & Moderately high \\
\hline S. macrophylla & Low & Low & High & Low & Low & Low \\
\hline T. lineata & High & High & High & High & High & Very high \\
\hline
\end{tabular}

${ }^{1}$ Low, where harvesting kills the tree; high, where the individual tree may survive harvesting

${ }^{2}$ Low, where harvesting is likely to lead to increased access to the forest (e.g. through road construction), leading to increased risk of conversion; high, where harvesting is unlikely to increase access to the forest

${ }^{3}$ Low, where the product is of low value or demand; high, where the product is of high value or demand (considered in the absence of legal constraints to harvesting, such as CITES or national legislation, which currently reduce or entirely prevent trade in some species)

${ }^{4}$ Low, where there is inequitable distribution of profit along the market chain, and/or where producers do not have property rights to the resource; high, where there is equitable distribution of profit along the market chain, and/or where the producers have property rights to the resource (considered in the absence of legal constraints to harvesting, such as CITES or national legislation, which currently reduce or entirely prevent trade in some species)

${ }^{5}$ Low, where producers do not have property rights to the resource; high, where the producers generally do have property rights to the resource

${ }^{6}$ Based on a combined assessment of the five conditions listed above. This is a summary of the potential for the approach to be successful, based on these five conditions, not a summary of whether or not conservation-through-use is currently being achieved in practice. 
For conservation to be effective all threats must be countered, not solely the risk of agricultural conversion. Few examples are available of income from the sale of forest products being used to support practical conservation action, for example the fencing of forest stands to exclude browsing herbivores, or management for fire protection. A. araucana provides an example of why this is necessary. Although the species is of high socio-economic and cultural value, many stands are deteriorating because of the effects of fire and browsing by livestock (Burns, 1993; Aagesen, 1998; Bekessy et al., 2002, 2004). Effectively, the species is being threatened by neglect.

One approach that is explicitly designed to provide a financial incentive for forest conservation is certification, which aims to promote sustainable forestry practices by assessment of forest management operations against a set of standards (Nussbaum \& Simula, 2005). Consumer preference for certified products should increase market share, resulting in higher returns to the producer communities. More than 100 million ha of forest have now been certified worldwide, under a variety of different certification schemes (Gullison, 2003). However, there is little direct evidence that forest certification has actually contributed to conservation (Rametsteiner \& Simula, 2003), partly because application of certification standards is sometimes inadequate (Schulze et al., 2008), and current incentives provided by certification are often insufficient to prevent overharvesting or deforestation (Gullison, 2003). Unsustainable harvesting ('liquidation logging') is typically much more profitable than sustainable forest management, particularly in tropical countries, where high discount rates, insecure land tenure, and economic uncertainty often prevail (Gullison, 2003).

\section{Discussion-achieving conservation through use}

As a result of their ecological characteristics and life history attributes, tree species offer higher potential for sustainable use than do many other organisms (Peters, 2001). Yet, in practice, trees appear to be little different from other species in being subjected to widespread over-exploitation. Despite initiatives such as forest certification and NTFP commercialization, there are still few successful examples of conservation-through-use being achieved for tree species.

Conservation-through-use clearly presents a challenging strategy for the conservation of tree species. Gullison (2003) suggested that financial resources may be better directed towards supporting alternative conservation approaches such as protected areas. However, as there are limits to the forest area that can be protected, conservation strategies are required for forests where trees are harvested (Fredericksen \& Putz, 2003). Rice et al. $(1997,2001)$ suggest protecting forest that has been lightly logged; once valuable timber species have been removed, the value of the land and hence the cost of protection can be considerably reduced (Rice et al., 2001). While this approach could contribute to the conservation of a forest, it contributes nothing to the conservation of the tree species being logged. To suggest that this is equivalent to dehorning the rhino (Gullison, 2003) is therefore misleading; whereas the individual rhino can survive dehorning, the tree species may not survive logging.

A wide range of factors prevent harvested species from being effectively conserved (Milner-Gulland \& Mace, 1998; Robinson, 2001; Hutton \& Leader-Williams, 2003). All of the tree species considered here are at risk from conversion of forest to agriculture, and many are being harvested illegally (Table 1). These examples suggest that even in those situations where harvesting is sustainable and successful commercialization is providing economic returns to producer communities, these returns are not being used to support practical conservation actions designed to counter other threats to the species.

Therefore, under what circumstances could conservation-through-use be effective for tree species? Based on the results of Marshall et al. (2006) and Newton et al. (2006), I propose five interventions:

Provision of external assistance External organizations, such as NGOs or government agencies, have a crucial role in supporting communities wishing to exploit their forest resources sustainably. In particular, producers require assistance in accessing market information and making links with traders and consumers. Assistance may be financial, in the form of credit or investment, or involve training and capacity building in areas such as forest inventory and management, business development and marketing.

Development of community organizations The importance of developing organizations to collect, process, transport and market forest products is widely appreciated by producers. Benefits include improved product quality and quantity, more cost-effective transportation and increased negotiating ability. Support to producer organizations, such as cooperatives or commercial networks, provides a useful focus for external assistance.

Implementation of assessment and monitoring $\mathrm{A}$ resource inventory is a fundamental component of a forest management plan. Monitoring harvesting impacts is an essential component of adaptive management approaches but there has been little attention to monitoring in the hundreds of projects aiming to conserve tropical forest through commercial exploitation (Peters, 1996). Approaches are required that enable producer communities themselves to perform monitoring, rather than depending on external support.

Provision of incentives The conservation-through-use approach ultimately depends on the value of the forest product, market demand, and the structure and function of 
market chains. Forest certification offers a potential mechanism to increase value, as do other niche-marketing approaches such as organic cocoa Theobroma cacao and fair trade initiatives (Marshall et al., 2006). However, certification represents an additional cost to producers, and therefore external financial support or subsidies may be required for the approach to be effective (Gullison, 2003; see also Schulze et al., 2008).

Protection against other threats Sustainable use, by itself, is insufficient to conserve a species, and Milner-Gulland \& Mace (1998) are incorrect in asserting that if use is sustainable then conservation is, by definition, being achieved'. This is because a species is typically exposed to threats other than solely use, and these threats may interact. Crucially, financial income from commercial exploitation of the resource is rarely used to support practical conservation action designed to counter other threats.

Sustainable forestry management does not guarantee sustainable use of a tree species. Conversely, managing for a sustainable harvest of a particular tree species does not guarantee sustainable forest management. There is therefore a tension between species conservation and forest conservation. This can best be understood in terms of the threats affecting an individual species versus those affecting the entire forest. The case of mahogany in Quintana Roo illustrates why it is important to understand these relationships. This example has benefited from the first four of the five interventions listed above but is still failing to conserve the main tree species being harvested (Kiernan, 2000; Snook, 2003, 2005). Species conservation efforts are being undermined by the additional threat of widespread illegal logging. Here, the problem is a lack of financial resources to address this threat by enforcing the legal controls that are in place (Kiernan, 2000).

If forest certification is failing to provide sufficient financial benefits for conservation to be effective (Gullison, 2003) then alternative types of incentive are required. Possibilities include payment for provision of ecosystem services (Balmford et al., 2002), such as carbon sequestration, as envisaged under the Kyoto protocol. Whatever services are provided, if incentive-driven conservation (Hutton \& Leader-Williams, 2003) is ever to be successful the financial rewards need to be large enough to support the conservation action required to ensure that all threats are adequately addressed.

\section{Acknowledgements}

I gratefully acknowledge the contributions made by collaborators involved in the research projects in which I have been involved, particularly the participants of CEPFOR, BIOCORES and SUCRE projects, and the various sponsors that supported this research.

\section{References}

A AGESEN, D.L. (1998) Indigenous resource rights and conservation of the monkey-puzzle tree (Araucaria araucana, Araucariaceae): a case study from Southern Chile. Economic Botany, 52, 146-160.

Allnutt, T.R., Newton, A.C., Lara, A., Premoli, A., Armesto, J.J., Vergara, R. et al. (1999) Genetic variation in Fitzroya cupressoides (alerce), a threatened South American conifer. Molecular Ecology, 8, 975-987.

Allnutt, T.R., Newton, A.C., Premoli, A. \& Lara, A. (2003) Genetic variation in the threatened South American conifer Pilgerodendron uviferum (Cupressaceae), detected using RAPD markers. Biological Conservation, 114, 245-253.

Balmford, A., Bruner, A., Cooper, P., Costanza, R., Farber, S., Green, R.E. et al. (2002) Economic reasons for conserving wild nature. Science, 297, 950-953.

Benessy, S.A., Allnutt, T.R., Premoli, A.C., Lara, A., Ennos, R.A., Burgman, M.A. et al. (2002) Genetic variation in the vulnerable and endemic monkey puzzle tree, detected using RAPDs. Heredity, 88, 243-249.

Bekessy, S.A., Newton, A.C., Fox, J.C., Lara, A., Premoli, A., Cortes, M. et al. (2004) The monkey puzzle tree in southern Chile. In Species Conservation and Management: Case Studies using RAMAS GIS (eds H.R. Açkakaya, M.A. Burgman, O. Kindval, P. Sjögren-Gulve, J. Hatfield \& M. McCarthy), pp. 48-63. Oxford University Press, Oxford, UK.

Brown, N., Jennings, S. \& Clements, T. (2003) The ecology, silviculture and biogeography of mahogany (Swietenia macrophylla): a review of the evidence. Perspectives in Plant Ecology, Evolution and Systematics, 6, 37-49.

BURns, B.R. (1993) Fire-induced dynamics of Araucaria araucanaNothofagus antarctica forest in the southern Andes. Journal of Biogeography, 20, 669-685.

Del Castillo, R.F. \& A costa, S. (2002) Ethnobotanical notes on Pinus strobus var. chiapensis. Anales del Instituto de Biología de la Universidad Autónoma de México Serie Botánica, 73, 319-327.

del Castillo, R.F., Pérez de la Rosa, J.A., Amado, G.V. \& Rivera García, R. (2004) Coníferas. In Biodiversidad de Oaxaca (eds A. García-Mendoza, M.J. Ordóñez \& M.A. Briones), pp. 141-158. Instituto de Biología, Universidad Nacional Autónoma de México, Fondo Oaxaqueño para la Conservación de la Naturaleza, WWF, México D.F., México.

Cicuzza, D., Newton, A.C. \& Oldfield, S. (2007) The Red List of Magnoliaceae. Fauna \& Flora International, Cambridge, UK.

CITES (2008) The CITES Appendices. Http://www.cites.org/eng/app/ index.shtml [accessed 2 February 2008].

Dickinson, M.B., Dickinson, J.C. \& Putz, F.E. (1996) Natural forest management as a conservation tool in the tropics: divergent views on possibilities and alternatives. Commonwealth Forestry Review, 75, 309-315.

FAO (2005) Forest Products Yearbook 2003. FAO, Rome, Italy.

Fearnside, P.M. (1997) Protection of mahogany: a catalytic species in the destruction of rain forests in the American tropics. Environmental Conservation, 24, 303-306.

Fredericksen, T.S. \& PUtz, F.R. (2003) Silvicultural intensification for tropical forest conservation. Biodiversity and Conservation, 12, $1445-1453$.

Freese, C.H. (1997) The 'Use it or lose it' debate: issues of a conservation paradox. In Harvesting Wild Species. Implications for Biodiversity Conservation (ed. C.H. Freese), pp. 1-48. John Hopkins University Press, Baltimore, USA.

Galindo-Jaimes, L., González-Espinosa, M., Quintana Ascencio, P. \& García-Barrios, L. (2002) Tree composition 
and structure in disturbed stands with varying dominance by Pinus spp. in the highlands of Chiapas, Mexico. Plant Ecology, $162,259-272$.

Gillies, A.C.M., Navarro, C., Lowe, A.J., Newton, A.C., Hernandez, M., Wilson, J. et al. (1999) Genetic diversity in Mesoamerican populations of mahogany (Swietenia macrophylla), assessed using RAPDs. Heredity, 83, 722-732.

González-Espinosa, M., Ramírez-Marcial, N. \& GalindoJAimes, L. (2006) Secondary succession in montane pine-oak forests of Chiapas, Mexico. In Ecology and Conservation of Neotropical Oak Forests. Ecological Studies 185 (ed. M. Kappelle), pp. 209-221. Springer-Verlag, Berlin, Germany.

Gubbi, S. \& MacMillan, D.C. (2008) Can non-timber forest products solve livelihood problems? A case study from Periyar Tiger Reserve, India. Oryx, 42, 222-228.

Gullison, R.E. (1998) Will bigleaf mahogany be conserved through sustainable use? In Conservation of Biological Resources (eds E.J. Milner-Gulland \& R. Mace), pp. 193-205. Blackwell Science, Oxford, UK.

Gullison, R.E. (2003) Does forest certification conserve biodiversity? Oryx, 37, 153-165.

Gullison, R.E., Panfil, S.N., Strouse, J.J. \& Hubbell, S.P. (1996) Ecology and management of mahogany in the Chimanes Forest, Beni, Bolivia. Botanical Journal of the Linnean Society, 122, 9-34.

Hellier, A., Newton, A.C. \& Ochoa Gaona, S. (1999) Use of indigenous knowledge for assessing trends in biodiversity: a case study from Chiapas, Mexico. Biodiversity and Conservation, 8, 869-889.

Herrmann, T.M. (2005) Knowledge, values, uses and management of the Araucaria araucana forest by the indigenous Mapuche Pewenche people: a basis for collaborative natural resource management in southern Chile. Natural Resources Forum, 29, 120-134.

HERRMANn, T.M. (2006) Indigenous knowledge and management of Araucaria araucana forest in the Chilean Andes: implications for native forest conservation. Biodiversity and Conservation, 15, $647-662$.

Holdsworth, A. \& Uhl, C. (1997) Fire in Amazonian selectively logged rain forest and the potential for fire reduction. Ecological Applications, 7, 713-725.

Homm A, A.K.O. (1996) Modernization and technological dualism in the extractive economy in Amazonia. In Current Issues in Nontimber Forest Products Research (eds M. Ruiz Pérez \& J.E.M. Arnold), pp. 59-82. CIFOR, Bogor, Indonesia.

Hutton, J. \& Dickson, B. (2001) Conservation out of exploitation: a silk purse from a sow's ear? In Conservation of Exploited Species (eds J.D. Reynolds, G.M. Mace, K.H. Redford \& J.G. Robinson), pp. 440-461. Cambridge University Press, Cambridge, UK.

Hutton, J.M. \& Leader-Williams, N. (2003) Sustainable use and incentive-driven conservation: realigning human and conservation interests. Oryx, 37, 215-226.

ITTO (International Tropical Timber Organization) (1990) Guidelines for the Sustainable Management of Natural Tropical Forests. Policy Development Series No. 1. ITTO, Yokohama, Japan.

IUCN (2007) 2007 IUCN Red List of Threatened Species. IUCN, Gland, Switzerland. Http://www.iucnredlist.org [accessed 25 January 2008].

Jensen, A. \& Meilby, H. (2008) Does commercialization of a nontimber forest product reduce ecological impact? A case study of the Critically Endangered Aquilaria crassna in Lao PDR. Oryx, 42, 214-221.

Johnson, N. \& CAbarle, B. (1993) Surviving the Cut: Natural Forest Management in the Humid Tropics. World Resources Institute, Washington, DC, USA.
Kiernan, M.J. (2000) The Forest Ejidos of Quintana Roo, Mexico. A Case Study for Shifting the Power: Decentralization and Biodiversity Conservation. Biodiversity Support Program, Washington, DC, USA.

Kusters, K., Achdiawan, R., Belcher, B. \& Ruiz Pérez, M. (2006) Balancing development and conservation? An assessment of livelihood and environmental outcomes of non-timber forest product trade in Asia, Africa, and Latin America. Ecology and Society, 11, article 20. Http://www.ecologyandsociety.org/vol11/iss2/ art20/ [accessed 16 January 2008].

Leakey, R.R.B. \& Newton, A.C. (eds) (1994) Tropical Trees: The Potential for Domestication and the Rebuilding of Forest Resources. HMSO, London, UK.

LudwiG, D. (2001) Can we exploit sustainably? In Conservation of Exploited Species (eds J.D. Reynolds, G.M. Mace, K.H. Redford \& J.G. Robinson), pp. 16-38. Cambridge University Press, Cambridge, UK.

MACE, G.M. \& Reynolds, J.D. (2001) Exploitation as a conservation issue. In Conservation of Exploited Species (eds J.D. Reynolds, G.M. Mace, K.H. Redford \& J.G. Robinson), pp. 3-15. Cambridge University Press, Cambridge, UK.

Marshall, E. \& Newton, A.C. (2003) Ecological impacts of NTFP extraction in Mexican cloud forest: a study from the Manantlan Cloud Forest Reserve, Jalisco. Economic Botany, 57, $262-278$.

Marshall, E., Newton, A.C. \& Schreckenberg, K. (2003) Commercialization of non-timber forest products: first steps towards analysis of the factors influencing success. International Forestry Review, 5, 128-137.

Marshall, E., Schreckenberg, K. \& Newton, A.C. (eds) (2006) Commercialization of Non-timber Forest Products: Factors Influencing Success. Lessons Learned from Mexico and Bolivia and Policy Implications for Decision-makers. UNEP-WCMC, Cambridge, UK.

Milner-Gulland, E.J. \& Mace, R. (1998) Conservation of Biological Resources. Blackwell Science, Oxford, UK.

Myers, G.P., Newton, A.C. \& Melgarejo, O. (2000) The influence of canopy gap size on natural regeneration of Brazil nut (Bertholletia excelsa) in Bolivia. Forest Ecology and Management, 127, 119-128.

Neumann, R.P. \& Hirsch, E. (2000) Commercialization of Nontimber Forest Products: Review and Analysis of Research. CIFOR, Bogor, Indonesia.

Newton, A.C. (1996) Does tree improvement conflict with the conservation of biodiversity? Agroforestry Forum, 7 , 2-5.

Newton, A.C. (ed.) (2007) Biodiversity Loss and Conservation in Fragmented Forest Landscapes. Evidence from Tropical Montane and Temperate Rain Forests in Latin America. CABI BioScience, Wallingford, UK.

Newton, A.C., Allnutt, T.R., Dvorak, W., Del Castillo, R. \& Ennos, R. (2002) Patterns of genetic variation in Pinus chiapensis, a threatened Mexican pine, detected by RAPD and mitochondrial DNA RFLP markers. Heredity, 89, 191-198.

Newton, A.C., Gow, J., Robertson, A., Williams-Linera, G., Ramírez-Marcial, N., González-Espinosa, M. et al. (2008) Patterns of genetic variation in two threatened endemic Mexican trees, Magnolia sharpii and Magnolia schiedeana. Silvae Genetica, in press.

Newton, A.C., Marshall, E., Schreckenberg, K., Golicher, D., Te Velde, D.W., Edouard, F. et al. (2006) Use of a Bayesian belief network to predict the impacts of commercializing non-timber forest products on livelihoods. Ecology and 
Society, 11, article 24. Http://www.ecologyandsociety.org/vol11/iss2/ art24/ [accessed 22 March 2007].

Newton, A.C. \& Soehartono, T. (2001) CITES and the conservation of tree species: the case of Aquilaria spp. in Indonesia. International Forestry Review, 3, 27-33.

Nussbaum, R. \& Simula, M. (2005) The Forest Certification Handbook. Earthscan, London, UK.

Oldfield, S., Lusty, C. \& MacKinven, A. (1998) The World List of Threatened Trees. UNEP-WCMC, Cambridge, UK.

Paoli, G.D., Peart, D.R., Leighton, M. \& Samsoedin, I. (2001) An ecological and economic assessment of the non-timber forest product gaharu wood in Gunung Palung National Park, West Kalimantan, Indonesia. Conservation Biology, 15, 1721-1732.

Peres, C.A., Baider, C., Zuidema, P.A., Wadt, L.H.O., Kainer, K.A., Gomes-Silva, D.A.P. et al. (2003) Demographic threats to the sustainability of Brazil nut exploitation. Science, 302, 2112-2114.

Peters, C.M. (1994) Sustainable Harvest of Non-Timber Plant Resources in Tropical Moist Forest: An Ecological Primer. Biodiversity Support Program, Washington, DC, USA.

Peters, C.M. (1996) Observations on the sustainable exploitation of non-timber tropical forest products: an ecologist's perspective. In Current Issues in Non-timber Forest Products Research (eds M. Ruiz Pérez \& J.E.M. Arnold), pp. 19-40. CIFOR, Bogor, Indonesia.

Peters, C.M. (2001) Lessons from the plant kingdom for conservation of exploited species. In Conservation of Exploited Species (eds J.D. Reynolds, G.M. Mace, K.H. Redford \& J.G. Robinson), pp. 242-256. Cambridge University Press, Cambridge, UK.

Plotkin, M. \& Famolare, L. (eds) (1992) Sustainable Harvest and Marketing of Rainforest Products. Conservation International and Island Press, Washington, DC, USA.

Premoli, A.C., Souto, C.P., Allnutt, T.R. \& Newton, A.C. (2001) Effects of population disjunction on isozyme variation in the widespread Pilgerodendron uviferum. Heredity, $87,337-343$.

Premoli, A.C., Souto, C.P., Rovere, A.E., Allnutt, T.R. \& Newton, A.C. (2002) Patterns of isozyme variation as indicators of biogeographic history in Pilgerodendron uviferum (D. Don) Florín. Diversity and Distributions, 8, 57-66.

Premoli, A.C., Vergara, R.A., Souto, C.P., Lara, A. \& Newton, A.C. (2003) Lowland valleys shelter the ancient conifer Fitzroya cupressoides in the Central Depression of southern Chile. Journal of the Royal Society of New Zealand, 33, 623-631.

Rametsteiner, E. \& Simula, M. (2003) Forest certification - an instrument to promote sustainable forest management? Journal of Environmental Management, 67, 87-98.

Rice, R.E., Sugal, C.A., Ratay, S.M. \& Fonseca, G.A. (2001) Sustainable forest management: a review of conventional wisdom. Advances in Applied Biodiversity Science, 3, 1-29.

Rice, R.E., Gullison, R.E. \& Reid, J.W. (1997) Can sustainable management save tropical forests? Scientific American, 276, 34-39.

Richards, E.M. (1993) The potential of non-timber forest products in sustainable natural forest management in Amazonia. Commonwealth Forestry Review, 72, 21-27.

Robinson, J.G. (2001) Using 'sustainable use' approaches to conserve exploited populations. In Conservation of Exploited Species (eds J.D. Reynolds, G.M. Mace, K.H. Redford \& J.G. Robinson), pp. 485-498. Cambridge University Press, Cambridge, UK.

Ros-Tonen, M.A.F. \& Wiersum, K.F. (2005) The scope for improving rural livelihoods through non-timber forest products: an evolving research agenda. Forests, Trees and Livelihoods, 15, 129-148.
Rowden, A., Robertson, A., Allnutt, T.R., Heredia, S., Williams-Linera, G. \& Newton, A.C. (2004) Conservation genetics of Mexican beech, Fagus grandifolia var. mexicana. Conservation Genetics, 5, 475-484.

Schulze, M., Grogan, J. \& Vidal, E. (2008) Forest certification in Amazonia: standards matter. Oryx, 42, 229-239.

Sheil, D. \& Wunder, S. (2002) The value of tropical forest to local communities: complications, caveats, and cautions. Conservation Ecology, 6, article 9. Http://www.consecol.org/vol6/iss2/art9 [accessed 22 March 2007].

Silla, F., Fraver, S., Lara, A., Allnutt, T.R. \& Newton, A.C. (2002) Regeneration and stand dynamics of Fitzroya cupressoides (Cupressaceae) in the Central Depression of Chile. Forest Ecology and Management, 165, 213-224.

SNOOK, L.K. (1996) Catastrophic disturbance, logging and the ecology of mahogany (Swietenia macrophylla King): grounds for listing a major tropical timber species on CITES. Botanical Journal of the Linnean Society, 122, 35-46.

SNOOK, L.K. (2003) Regeneration, growth and sustainability of mahogany in México's Yucatán forests. In Big-leaf Mahogany: Genetics, Ecology and Management (eds A.E. Lugo, J. Figueroa-Colón \& M. Alayón), pp. 169-192. Springer-Verlag, New York, USA.

SNOOK, L.K. (2005) Sustaining mahogany: research and silviculture in Mexico's community forests. Bois et Forêts des Tropiques, 285, $55-65$.

Soehartono, T. \& Newton, A.C. (200o) Conservation and sustainable use of tropical trees in the genus Aquilaria. I. Status and distribution in Indonesia. Biological Conservation, 96, 83-94.

Soemartono, T. \& Newton, A.C. (2001) Conservation and sustainable use of tropical trees in the genus Aquilaria. II. The impact of gaharu harvesting in Indonesia. Biological Conservation, 97, 29-41.

Soemartono, T. \& Newton, A.C. (2002) The gaharu trade in Indonesia: is it sustainable? Economic Botany, 56, 271-284.

Strandby Andersen, U., Córdova, J.P.P., Nielsen, U.B., Olsen, C.S., Nielsen, C., Sørensen, M. \& Kollmann, K. (2008) Conservation through utilization: a case study of the Vulnerable Abies guatemalensis in Guatemala. Oryx, 42, 206-213.

Téllez-Valdés, O., Dávila-Aranda, P. \& Lira-Saade, R. (2006) The effects of climate change on the long-term conservation of Fagus grandifolia var. mexicana, an important species of the cloud forest in Eastern Mexico. Biodiversity and Conservation, 15, 1095-1107.

Wевв, G. (2002) Conservation and the sustainable use of wildlife an evolving concept. Pacific Conservation Biology, 8, 12-26.

Weddell, B.J. (2002) Conserving Living Natural Resources. Cambridge University Press, Cambridge, UK.

WiERSUM, K.F. (1995) 200 years of sustainability in forestry: lessons from history. Environmental Management, 19, 321-329.

Williams-Linera, G., Rowden, A. \& Newton, A.C. (2003) Distribution and stand characteristics of relict populations of Mexican beech (Fagus grandifolia var. mexicana). Biological Conservation, 109, 27-36.

\section{Biographical sketch}

AdRian Newton has more than 20 years' experience researching forest conservation ecology, including the conservation and sustainable use of threatened tree species. He is currently Director of the Centre for Conservation Ecology and Environmental Change at Bournemouth University, UK, and is also Vice-Chair of the IUCN/ SSC Global Tree Specialist Group. His current research interests include the restoration of tropical dry forests and analysis of species loss in fragmented forest landscapes. 